\title{
Acknowledgments
}

The debts that have accumulated around this book defy repay1 ment by mere mention, but mentioned they must be. My thinking about Locke, liberalism, and the history of political thought owes much to Sheldon Wolin, under whose ministrations this research first began. The exemplary friendship of Teresa de Lauretis urged it along, gave it a home, and helped it prosper. The form in which it now appears profited greatly-though perhaps not so much as they might wish-from the generous comments and incisive criticism of Donald Moon, Nancy Hirschmann, Richard Flathman, and William Connolly. One benefits, of course, as much from the spirit of collegiality as from the letter of criticism. On this count, the Johns Hopkins University has proved more than congenial as a place to work the fence-lines between history and theory. The Hopkins history department deserves special mention, both for its general ambience and for the particular virtue of its weekly collocation in "the Seminar." I am grateful as well for ongoing conversations with J. G. A. Pocock, Gabrielle Spiegel, and Dorothy Ross in History, Jonathan Goldberg, Mary Poovey, and John Guillory in English, Jerome Schneewind in Philosophy, Nancy Streuver in the Humanities Center, and Katherine Verdery in Anthropology. Whatever merits this book might have are inseparable from the support and encouragement of these friends and colleagues.

This project has been furthered by a number of institutions as well. Initial research was supported by a National Science Foundation fellowship and a summer grant from the Committee on European Studies at Princeton University. The political science department at Johns Hopkins University has been generous with release time and with support for the graduate students whose labors 
greatly eased its completion. Next to last, then, but far from least, I want to thank Jennifer Thomas, Jason Frank, Carol Pech, Mark Cushman, and Davide Panagia for their able assistance.

Finally, it has been a pleasure to work with the editors and staff of Cornell University Press. The good will, good humor, and good sense of Roger Haydon, in particular, have been greatly appreciated.

K. M. M. 


\section{JUDGING RIGHTS}


